誘導体化 HPLC 法による製剤中ステアリン酸マグネシウムの迅速分離定量法の確立

\author{
新井 隆, ${ }^{*}$ 細井康 江
}

\title{
Determination of Magnesium Stearate in Pharmaceutical Preparations Using Derivatization with 2-Nitrophenylhydrazine and HPLC
}

\author{
Takashi ARAI* and Yasue HosoI \\ Pharmaceutical Technology Research Laboratories, Tokyo Pharmaceutical Research Center, Daiichi \\ Pharmaceutical Co., Ltd., 1-16-13 Kita-kasai, Edogawa-ku, Tokyo 134-8630, Japan
}

(Received October 25, 2004; Accepted December 16, 2004)

\begin{abstract}
In general, spectrophotometric methods (inductively coupled plasma or atomic absorption spectrophotometry) are used for the assay of magnesium stearate $(\mathrm{Mg}-\mathrm{St})$. In this study, a new rapid, selective assay method was developed for $\mathrm{Mg}-\mathrm{St}$ in pharmaceutical formulations. The method was based on isocratic reverse-phase liquid chromatography using a mobile phase of acetonitrile-water $(80: 20, \mathrm{v} / \mathrm{v})$ after precolumn derivatization with 2-nitrophenyl hydrazine for sensitive UV detection. Margaric acid was used as an internal standard and the substances were detectable at $230 \mathrm{~nm}$ or 400 $\mathrm{nm}$. Using a short $(2 \mathrm{~cm})$ HPLC column reduced the analytical time to $5 \mathrm{~min}$. Validation of the newly developed method was performed in accordance with the International Conference on Harmonization guidelines. The linearity range for $\mathrm{Mg}-\mathrm{St}$ was $0.00-0.04 \mathrm{mg} / \mathrm{ml}$ (as the concentration of injected sample solution) and their correlation factor was 0.9998 . The determination and detection limits for $\mathrm{Mg}-\mathrm{St}$ were $6 \mu \mathrm{g}$ and $2 \mu \mathrm{g}$, respectively. The proposed method was successfully applied to the determination of trace amounts of $\mathrm{Mg}-\mathrm{St}$ in commercially available tablets with a high recovery percentage, good accuracy, and precision.
\end{abstract}

Key words_ assay; magnesium stearate; HPLC; precolumn derivatization; pharmaceutical preparation; analytical procedure validation

緒 言

日本薬局方ステアリン酸マグネシウム $(\mathrm{Mg}-\mathrm{St})$ は，ステアリン酸とパルミチン酸のマグネシウム $(\mathrm{Mg})$ 塩の混合組成からなり，金属石畭（有機酸金 属塩）として分類される水性溶媒及び有機溶媒の大 多数に難溶性の化学的に安定な物質である. 工業的 な用途の歴史は古く, 欧州の産業革命以後, 塗料の 乾燥剂，潤滑剂，繊維関係の撥水剂などとして用い られてきた. ${ }^{1)}$ 一方，製剤分野では錠剂及びカプセ ル剂の滑沢剂，潤滑剤又は付着防止剂として現在も 汎用されている.

このように, $\mathrm{Mg}-\mathrm{St}$ は歴史的にも種々の産業分 野で使用されている化合物であるが，その分析法に ついてはあまり報告がなく，現在も薬局方などの公

第一製薬株式会社製剤技術研究所・東京製剤技術セン 夕一

e-mail: arait26d@daiichipharm.co.jp
定書には定量法として，キレート滴定法が収載され ている. ${ }^{1,2)}$

近年，製剂技術分野では外部滑沢打錠技術が進歩 してきており，それに伴い錠剂表面に付着している $\mathrm{Mg}-\mathrm{St}$ 量を少量のサンプルで簡易, 精度よく把握 する必要が生じている。昨今では分光学的機器分析 技術が進歩し, $\mathrm{Mg}-\mathrm{St}$ の微量分析法としてマグネ シウム（Mg）を指標とした inductivel coupled plasma (ICP） 法 ${ }^{3)}$ あるいは原子吸光法4)などの方法が 報告されている。しかし，錠剤中に $\mathrm{Mg}-\mathrm{St}$ と同じ $<\mathrm{Mg}$ を含む副原料として，例えばメタケイ酸アル ミン酸マグネシウム (ノイシリン), ケイ酸マグネ シウム, 炭酸マグネシウムなどを用いている場合, 指標となる $\mathrm{Mg}$ の量が副原料由来の $\mathrm{Mg}$ と重複する ため, 非分離分析法である分光学的方法を用いて直 接 $\mathrm{Mg}-\mathrm{St}$ を定量することは困難である.

また，日本薬局方及び米国薬局方（USP）の Mg -St の純度試験として収載されている GCによる試 
験法 ${ }^{1,2)}$ は，それまでのマグネシウムを指標とする ものではなく，構成成分であるステアリン酸及びパ ルミチン酸に着目し，それらの分離分析を達成して いるものの，比較的多量の試料（Mg-St として $0.10 \mathrm{~g})$ を必要とし, さらに，三フッ化ホウ素・メ タノールの存在下，加熱還流反応によるメチルエス テル化後, キャピラリー GC に付す繁雑な方法であ るため, 錠剤中に含まれる微量の $\mathrm{Mg}-\mathrm{St}$ を多検体 処理・迅速測定するには適していない.

一方, $\mathrm{Mg}-\mathrm{St}$ の分離分析法を確立する際に，一 般的な分離モードである逆相系 HPLC を選択する 場合の問題点としては，(1)疎水性が高いため保持時 間（分析時間）が長くなること，(2)紫外部の吸収が 小さいため検出感度が低いなどが挙げられる。近年 では hyphenated analysis の著しい進歩に伴い, 高 速液体クロマトグラフ質量分析計（LC-MS）によ る長鎖脂肪酸の分析も数例試みられているが, ${ }^{5,6)}$ い ずれの例も 9-anthrylmethyl ester 誘導体として分析 するものであり，試薬の安定性に起因する操作性及 び LC-MS が紫外吸光検出 HPLC に比べて高価で ある点からも日常的分析法として使用するには一般 的ではない

HPLC 検出技術の進展に視点を転じてみると, 一般にアミノ基に比べ誘導体化が難しいとされてい たカルボキシル基についても, 近年 UV, 蛍光検出 用の有用な誘導体化試薬が開発されてきてお り, 7-9）容易に高感度検出可能な発色団基（chromophore）を導入できることから，主に生体成分の 分析を中心に種々の応用が報告されてきている.

また，HPLC カラムについては，ハイスループ ットスクリーニング分析 (high throughput screening：HTS）への応用を中心に，粒径 $5 \mu \mathrm{m}$ 以下の充 てん剤の実用化が進み, 長さ $5 \mathrm{~cm}$ 以下のカラムで も従来の分離能を維持したまま短時間（5-10 分以 内）での分析が可能となってきている. ${ }^{10,11)}$

前述のごとく, $\mathrm{Mg}$ を含む製剂副原料を使用して いる場合，実用的な製剤中の $\mathrm{Mg}-\mathrm{St}$ 分析法は確立 されていない，本報告では，錠剂中に含まれる微量 $\mathrm{Mg}-\mathrm{St}$ の分離分析法の確立を目的とし，主構成成 分であるパルミチン酸及びステアリン酸の和を指標 とし，それらの簡易な高感度プレカラム誘導体化を 確立した。さらにショートカラムを用いた HPLC に付すことにより短時間（5 分以内）で分離可能な
高感度分析法の設定ができた，次に，実製剤への適 用可能性を評価するために，International Conference on Harmonization（ICH）ガイドライン及び日 局の分析法バリデーションに準拠した特異性，真 度，直線性，精度及びシステム適合性試験について データを測定した．最後に，Mg-St 定量法の実用 化検討として，既に市販されている製剂（錠剂，力 プセル剂） 4 品目について, $\mathrm{Mg}-\mathrm{St}$ 含量の測定を行 った.

\section{実 験 の 部}

狂牛病（BSE）問題に端を発した動物性 $\mathrm{Mg}-\mathrm{St}$ と植物性 $\mathrm{Mg}-\mathrm{St}$ との品質同等性の確保にも関連 し, 各 $\mathrm{Mg}-\mathrm{St}$ の脂肪酸組成についても, 論議の的 となることが予想された。そのため本報では， $\mathrm{Mg}-$ St 由来のステアリン酸ピークとパルミチン酸ピー クの分離を達成した上で, $\mathrm{Mg}-\mathrm{St}$ の含量として は，ステアリン酸ピークとパルミチン酸ピークの総 和をもって表すこととし，以下の検討を行った.

1. 試料分析条件確立及び分析法バリデーシ ヨンの際には重量約 $100 \mathrm{mg}$ のプラセボ錠を使用し た。プラセボ錠は乳糖に滑沢剂として $\mathrm{Mg}-\mathrm{St}$ ，流 動化剂としてメタケイ酸アルミン酸マグネシウム (ノイシリン)，その他に粉末セルロース，ケイ酸カ ルシウム, クロスポピドン, ヒドロキシプロピルセ ルロースを添加し，乳糖含量が約 $80 \%$ となるよう に第一製薬侏製剂技術研究所・東京製剂技術セン ターで外部滑沢打錠法により試作されたものを使用 した。ただし，真度（回収率）測定の際には，同組 成からなる粉末に $\mathrm{Mg}-\mathrm{St}$ の既知量を添加し，試料 とした.

2. 試薬 $\mathrm{Mg}-\mathrm{St}$ は，製剤の製造用に用いられ ている日東化成工業製のものを使用した。クロマト グラム上での溶出位置確認のため標品として用いた ステアリン酸，パルミチン酸，及び内標準物質とし て用いたマーガリン酸は各々，東京化成より試薬と して購入した。2-nitrophenylhydrazine (2-NPH) 誘導体化には，侏ワイエムシィ社で販売している誘 導体化試薬キット（製品番号：XSRFAR01）を使 用した。すなわち，2-NPH 試液，縮合剂である 1ethyl-3- ( 3-dimethylaminopropyl ) carbodiimide （EDC）試液及び反応停止試液である水酸化カリウ ム（KOH）試液を，キットの説明書を参考に 
Miwa ら $^{8,9)}$ の方法に従い順次添加し誘導体化操作を 行った. HPLC 溶媒は HPLC 用のものを，その他 の試薬類については試薬（特級）を使用した。

\section{3. 実験装置 HPLC 装置は，WATERS 社の} モジュール：Alliance 2697 Upgrade を用い，デー 夕の解析に Millennium 32（Ver 3.06.01）を使用し た.カラムは WATERS 社の Symmetry C18 (4.6× $20 \mathrm{~mm}, 3.5 \mu \mathrm{m}$ ）を使用した.

試料の前処理の際に使用したヒーティングブロッ クは，アズワン侏製ドライブロックバス EB-603 で ある。

4. プレカラム誘導体化による HPLC 分析条件 の検討

4-1. 錠剂中 $\mathrm{Mg}-\mathrm{St}$ の誘導体化 誘導体化の 検討は, Miwa らの報告8,9) を参考に, 脂肪酸のカル ボキシル基に着目し，縮合剂（EDC）の存在下で 2-NPH との反応を市販の試薬キットを用いて行っ た。誘導体化は，有機溶媒抽出などを行わず，直 接，錠剂に試薬を添加する方法を検討した．試料前 処理操作を含む誘導体化のフローチャートを Fig. 1
に示す.

4-2. 分析法バリデーション 錠剤中に存在す る $\mathrm{Mg}-\mathrm{St}$ の定量的誘導体化を含めた分析法の妥当 性を示すため, ICH ガイドライン及び日局の分析 法バリデーションに準拠し，特異性，真度（回収 率)，直線性，精度及びシステム適合性試験につい て検討を行った。

特異性では，共存するほかの製剤副原料及び誘導 体化の際の副反応生成物がパルミチン酸誘導体，又 テアリン酸誘導体及び内標準物質であるマーガリン 酸誘導体の各溶出位置に影響を及ぼさないことを, $\mathrm{Mg}-\mathrm{St}$ を含まないプラセボ粉末について同様の誘 導体化反応を行い，そのクロマトグラムを比較して 確認した.

真度は $\mathrm{Mg}-\mathrm{St}$ を含まないプラセボ製剤成分粉末 に，既知量の $\mathrm{Mg}-\mathrm{St}$ を添加し，その回収率を求め ることで算出した。なお，含量水準は，100 mg 製 剂を定めた操作により分析した場合に想定される $0.1 \mathrm{w} / \mathrm{w} \%$ ，すなわち $0.1 \mathrm{mg}$ を $100 \%$ とし，限度試 験に準ずるものとして 50\%, 100\%, 150\%の 3 水準

Take a tablet or grinded powder about $0.1 \mathrm{mg}$ as $\mathrm{Mg}-\mathrm{St}$

Stand for a few minutes

$$
\downarrow \leftarrow \text { Ethanol } 200 \mu \mathrm{L}
$$

$\downarrow \leftarrow$ I.S. (margaric acid) soln. $: 100 \mu \mathrm{L}$

Mixing

$\downarrow \leftarrow 2$-NPH soln. $: 200 \mu \mathrm{L}$

Mixing

$$
\downarrow \leftarrow \text { EDC soln. : } 200 \mu \mathrm{L}
$$

Allowed to react at $60^{\circ} \mathrm{C}$ for $20 \mathrm{~min}$.

$\downarrow \leftarrow$ Alkaline solution $: 200 \mu \mathrm{L}$

Mixing

Holding at $60^{\circ} \mathrm{C}$ for $15 \mathrm{~min}$.

$\downarrow$

Cooling at room temp.

$$
\downarrow \leftarrow \text { Methanol }
$$

To make $5 \mathrm{~mL}$<smiles>[CH]1CC1</smiles>

Filtrate

(Millex-LH $0.45 \mu \mathrm{m}, 13 \mathrm{~mm}$, Millipore)

Injection into HPLC

Fig. 1. Preparation Procedure of Magnesium Stearate from Tablets Derivatization method is according to Ref. 8 and 9. 
について回収率を測定した。また，この 3 水準 $(n$ =3）の繰返しデータは, 併行精度の評価データと しても採用し，9回の回収率の相対標準偏差 (RSD) を求めた.

直線性は HPLC 注入時の $\mathrm{Mg}-\mathrm{St}$ 濃度として $0.0005,0.001,0.002,0.01,0.02,0.04 \mathrm{mg} / \mathrm{ml}$ の 6 点 について評価を行つた。 また, 定量限界, 検出限界 については別途，予測された各限界近傍域での検量 線 $(0.0005,0.001,0.002 \mathrm{mg} / \mathrm{ml})$ の回帰式の傾き (S) とレスポンスの標準偏差 $(\sigma)$ を求め, 検出限 界 $(\mathrm{DL})=3.3 \sigma / \mathrm{S}$ ，定量限界 $(\mathrm{QL})=10 \sigma / \mathrm{S}$ によ り算出した.

一方，システム適合性試験としては，I.S. を含む $\mathrm{Mg}-\mathrm{St}$ 標準溶液を用いて，ピーク面積比及び隣接 するピークとの分離度（Rs）について繰り返し 6 回注入時の再現性を試験した。

\section{4-3. 錠剤中の $\mathrm{Mg}-\mathrm{St}$ の定量 以上のバリ} デーション結果を考慮し，以下に示す分析法を確立 した.

『本品若しくは粉研した粉末の， Mg-St として約 $0.1 \mathrm{mg}$ に相当する量を精密に量り，エタノール 200 $\mu \mathrm{l}$ を加えて潤し約 3 分放置し, 内標準溶液 $100 \mu \mathrm{l}$ を 加えて（ボルテックスミキサーを用いて）激しく攪 汼する。試薬 A（ラベル化剂：2-NPH 溶液） $200 \mu \mathrm{l}$ を加えて攪汼し，さらに試薬 B（縮合剂：EDC 溶 液） $200 \mu \mathrm{l}$ を加えて攪汼する。蓋をして $60^{\circ} \mathrm{C}$ で 20 分間加温する。試薬 C（反応停止剂： $\mathrm{KOH}$ 溶液） $200 \mu \mathrm{l}$ を加えて攪汼し，蓋をして $60^{\circ} \mathrm{C}$ で 15 分間加 温する。室温まで冷却してメタノールを加えて 5 $\mathrm{ml}$ とした液を $0.45 \mu \mathrm{m}$ のフィルターを用いてろ過 し, 試料溶液とする.

別に, $\mathrm{Mg}-\mathrm{St}$ 約 $10 \mathrm{mg}$ を精密に量り，エタノー ルを加えて正確に $20 \mathrm{ml}$ とする．懸濁状態の液を攪 拌しながら， $200 \mu \mathrm{l}$ とり，内標準溶液 $100 \mu \mathrm{l}$ を加え て激しく攪汼する。試薬 A $200 \mu \mathrm{l}$ を加えて攪汼 し，さらに試薬 B $200 \mu \mathrm{l}$ を加えて攪汼する。蓋を して $60^{\circ} \mathrm{C}$ で 20 分間加温する。試薬 $\mathrm{C} 200 \mu \mathrm{l}$ を加

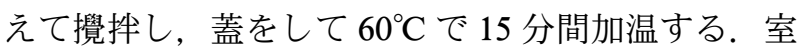
温まで冷却してメタノールを加えて $5 \mathrm{ml}$ とした液 を $0.45 \mu \mathrm{m}$ のフィルターを用いてろ過し，標準溶液 とする.

試料溶液及び標準溶液 $20 \mu \mathrm{l}$ につき，次の条件で 液体クロマトグラフ法により試験を行い，それぞれ
の液のパルミチン酸ピークとステアリン酸ピークの 面積和と内標準物質ピークの面積との比 $Q_{T}$ 及び $Q_{S}$ を求める.

試験条件

紫外吸光光度計（測定波長 : $230 \mathrm{~nm}$ )

カラム：内径 $4 \mathrm{~mm}$, 長さ $2 \mathrm{~cm}$ のステンレス管 に $3.5 \mu \mathrm{m}$ の液体クロマトグラフ用オクタデシルシ リル化シリカゲルを充てんする。（例：Symmetry $\mathrm{C} 18,4.6 \times 20 \mathrm{~mm}$ (Waters 社))

カラム温度 : $35^{\circ} \mathrm{C}$ 付近の一定温度

移動相：アセトニトリル/水混液（80：20)

流量 : $1.2 \mathrm{ml} / \mathrm{min}$.

内標準溶液 : マーガリン酸のエ夕ノール溶液（1 $\rightarrow 2000)$

試液（ラベル化剂，縮合剤及び反応停止剂）はワ イエムシィ社から発売されている遊離型短鎖・長鎖 脂肪酸分析キット（XSRFA01）を用いた.

試料中の $\mathrm{Mg}-\mathrm{St}$ 含量は次式により算出した.

試料中の $\mathrm{Mg}-\mathrm{St}$ 含量 $(\mathrm{mg})=\frac{W_{s}}{10} \times \frac{Q_{T}}{Q_{S}} \times 0.1$

$W_{s}:$ 標準溶液調製用 $\mathrm{Mg}-\mathrm{St}$ の秤取量 $(\mathrm{mg})$

\section{結果及び考察}

1. 誘導体化による分析法の確立 2-NPH は 縮合剂である EDC の存在下，カルボキシル基と反 応し, 対応するヒドラジッド誘導体を与える.

本法では有機溶媒抽出を行わず，錠剤そのまま， 若しくは粉砕した粉末に内標準物質を含むエタノー ルを加えて潤し，そこに直接誘導体化試薬を順次， 添加することで酸による $\mathrm{Mg}-\mathrm{St}$ からのマグネシウ ム遊離操作を行わずして直接，ステアリン酸及びパ ルミチン酸に対応する 2- ニトロフェニルヒドラジ ッドを得ることができた。本反応により得られたヒ ドラジッドは紫外部吸収波長 $230 \mathrm{~nm}$ 若しくは 400 $\mathrm{nm}$ で高感度な検出が可能であった。 内標準物質で あるマーガリン酸を含む典型的なクロマトグラム例 を Fig. 2(b) に示す.

標準溶液を用いて比較したところ，非誘導体化試 料の $210 \mathrm{~nm}$ での直接検出に比べ，約 300 倍以上の 高感度化が達成できた。 また，ショートカラムを用 いたところ，疎水性の高い長鎖脂肪酸誘導体にも関 わらず，各ヒドラジッド誘導体は逆相 HPLC 上で 5 分以内での相互分離が可能であった。ささらに誘導 

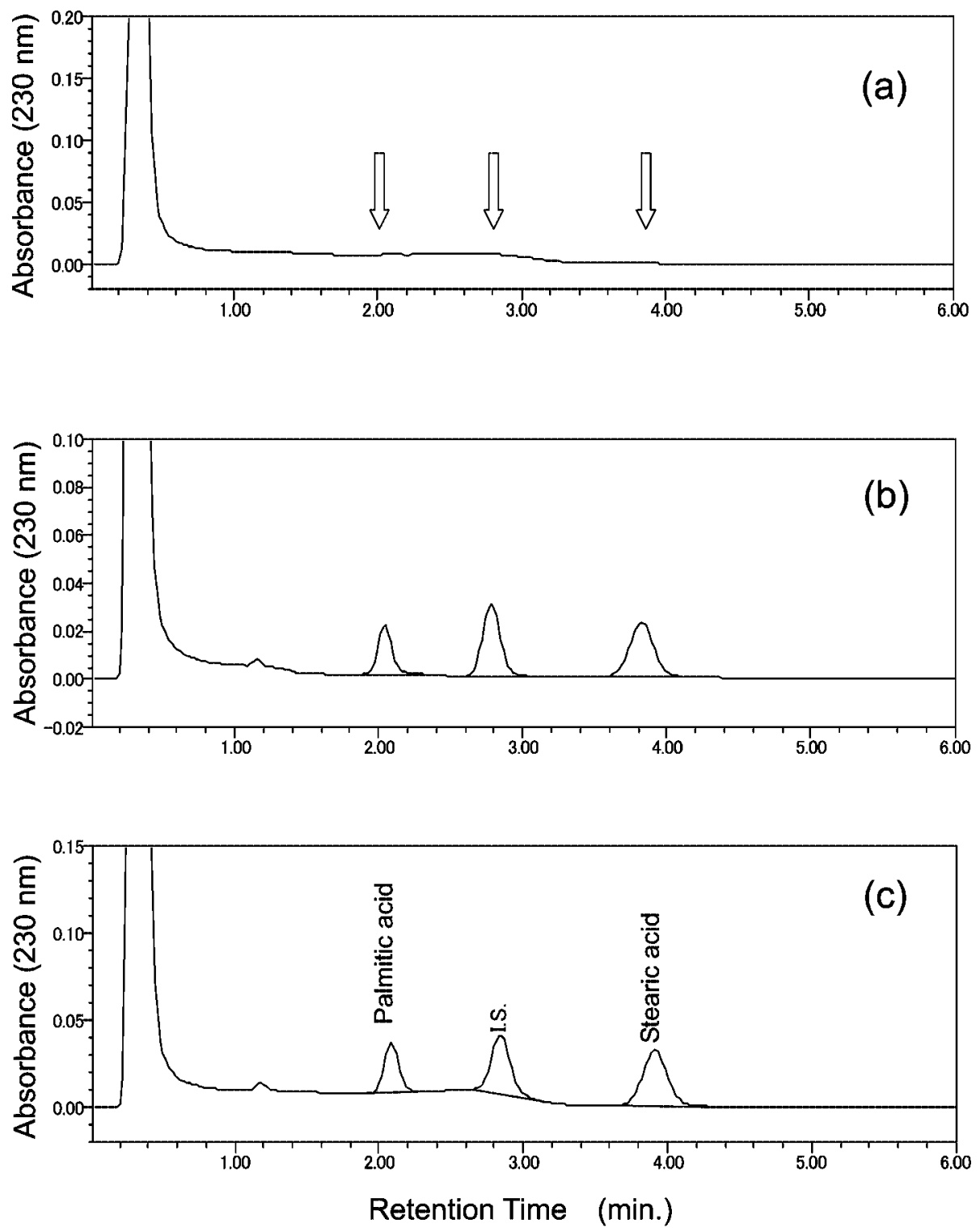

Fig. 2. Validation of Analytical Procedures

(a) Blank tablet (Mg-St free), (b) Mg-St standard solution, (c) Tablet. Mobile phase, acetonitrile-water (80:20), flow rate, 1.2 ml/min. Column: Symmetry C18 $\left(4.6 \times 20 \mathrm{~mm}, 3.5 \mu \mathrm{m}\right.$, WATERS), Column temperature: $35^{\circ} \mathrm{C}$, Injection volume: $20 \mu$ l, Peaks: $1=$ palmitic acid, $2=$ margaric acid $(\mathrm{I} . \mathrm{S}$.), $3=$ stearic acid.

体化反応の過程で生成した副反応物質 (by-product) は，クロマトグラムのフロント付近に集中して溶出 し, Mg-St 由来のステアリン酸及びパルミチン酸 ピークへの影響はみられなかった。

次項に「分析バリデーション」の結果として詳細 を示す.

2. 分析法バリデーション Figure 2 に $\mathrm{Mg}-\mathrm{St}$ 標準溶液， $\mathrm{Mg}-\mathrm{St}$ を含むプラセボ錠及びブランク 試料を各々試験法に従い誘導体化操作を行つた際の クロマトグラムを示す. $\mathrm{Mg}-\mathrm{St}$ を含むプラセボ錠 から得られたクロマトグラム (c)では， Mg-St の構 成成分であるステアリン酸とパルミチン酸誘導体の
溶出位置付近に他の成分のピークによる妨害は認め られず，かつブランク試料の誘導体化クロマトグラ ム (a) 上でも $\mathrm{Mg}-\mathrm{St}$ 関連物質溶出位置に他成分の ピークが認められないことから，設定した誘導体化 法及び HPLC の分析条件の特異性が確認された.

真度について，50\%，100\%及び 150\%の 3 濃度で 繰り返し 3 回の添加回収実験を行った結果を Table 1 に示す。各濃度間で多少のバラツキが認められた ものの，誘導体化操作を含んだ製剂中副原料の微量 分析法としては良好な值であると判断された。

直線性に関して，製剤 $100 \mathrm{mg}$ を秤取した場合に $\mathrm{Mg}-\mathrm{St}$ として $0.1 \%$ に相当する量を含む 6 点の濃度 
Table 1. Accuracy

\begin{tabular}{cccc}
\hline \hline \multirow{2}{*}{ Repetition } & \multicolumn{3}{c}{ Recovery value (\%) } \\
\cline { 2 - 4 } & $\begin{array}{c}50 \% \\
(0.05 \mathrm{mg})\end{array}$ & $\begin{array}{c}100 \% \\
(0.1 \mathrm{mg})\end{array}$ & $\begin{array}{c}150 \% \\
(0.15 \mathrm{mg})\end{array}$ \\
\hline 1 & 100.5 & 94.1 & 92.5 \\
2 & 101.1 & 97.2 & 98.3 \\
3 & 96.3 & 96.7 & 95.2 \\
Average (\%) & 99.3 & 96.0 & 95.3 \\
S.D. & 2.615 & 1.664 & 2.902 \\
RSD (\%) & 2.63 & 1.73 & 3.05 \\
\hline Total average (\%) & & 96.9 & \\
Total S.D. & \multicolumn{3}{c}{2.80} \\
Total RSD (\%) & \multicolumn{3}{|}{2.89} \\
\hline
\end{tabular}

（検量線範囲 注入時試料濃度として：0.00-0.04 $\mathrm{mg} / \mathrm{ml},[\mathrm{Mg}-\mathrm{St}$ として $0.1 \mathrm{mg}$ の試料を秤取した場 合の $0-0.2 \%$ に相当]）で検量線を作成したとこ ろ，パルミチン酸のピーク面積比とステアリン酸の ピーク面積比の合計值と濃度の関係は Table 2 に示 すように相関係数 0.999 以上が得られた. さらに回 帰式の切片の $95 \%$ 信頼区間は「0」を挟むところか ら，本検量線は原点を通る良好な直線であると判断 した。また，検出限界及び定量限界が予測された低 濃度域 $(0.5-2 \mu \mathrm{g} / \mathrm{ml})$ で得られた回帰式から, 傾 き（S）とレスポンスの標準偏差（ $\sigma$ ) を求め, 検 出限界 $(\mathrm{DL})=3.3 \sigma / \mathrm{S}$, 定量限界 $(\mathrm{QL})=10 \sigma / \mathrm{S}$ を求めたところ, Table 2 に示すように各々 $2 \mu \mathrm{g}$ 及 び $6 \mu \mathrm{g}$ と，限度試験に準ずる試験項目としては十 分な值を示した.

回収率を測定したときの 3 水準, 繰り返し 3 回の 回収率から精度を評価したところ, Table 1 に示し たように得られた RSD（\%）は2.9\%であった。こ れらの結果は, 真度と同様, 本法が誘導体化操作を 含んだ製剤中副原料の微量分析法であることを考慮 すると, 十分妥当な值であると判断した.

さらに，試験毎に実施するシステム適合性試験と して Mg-St 標準溶液の繰り返し 6 回注入時の再現 性を検討した。 その結果を Table 3 に示す。内標準 物質のピーク面積に対するステアリン酸とパルミチ ン酸のピーク面積合計の比の RSD（\%）は $1.3 \%$ で あり，また，ステアリン酸，パルミチン酸及び内標 準物質の相互間の分離度 $(R \mathrm{~s})$ は 3.5 以上であり, いずれも良好な結果であった。

以上の分析法バリデーション結果より, $\mathrm{Mg}-\mathrm{St}$
Table 2. Linearity, Detection Limit (DL) and Quantitation Limit (QL) of Magnesium Stearate

\begin{tabular}{|c|c|}
\hline $\begin{array}{l}\text { Range of calibration curve } \\
\text { (for linearity) }\end{array}$ & $0.5 \mu \mathrm{g} / \mathrm{ml}-0.04 \mathrm{mg} / \mathrm{ml}$ \\
\hline Correlation coefficient: $(r)$ & 0.9998 \\
\hline Slope & 79.97 \\
\hline Intercept & -0.064 \\
\hline \multirow{2}{*}{$\begin{array}{l}\text { Confidence interval (95\%) } \\
\text { of intercept }\end{array}$} & 0.4278 \\
\hline & -0.5559 \\
\hline $\begin{array}{l}\text { Range of calibration curve } \\
\text { (for calculation of DL and QL) }\end{array}$ & $0.5 \mu \mathrm{g} / \mathrm{ml}-2 \mu \mathrm{g} / \mathrm{ml}$ \\
\hline$\sigma$ & 62.5 \\
\hline S & 0.0076 \\
\hline Detection limit（DL） & $2 \mu \mathrm{g}$ \\
\hline Quantitation limit（QL) & $6 \mu \mathrm{g}$ \\
\hline
\end{tabular}

Table 3. System Suitability Test

\begin{tabular}{cccc}
\hline \hline Repetition & $\begin{array}{c}\text { Ratio of } \\
\text { peak area }\end{array}$ & $\begin{array}{c}\text { Resolution }(R S) \\
\text { Stearate vs. I.S. }\end{array}$ & $\begin{array}{c}\text { Resolution }(R S) \\
\text { Palmitate vs. I.S. }\end{array}$ \\
\hline 1 & 1.55 & 3.84 & 3.56 \\
2 & 1.57 & 3.85 & 3.59 \\
3 & 1.53 & 3.84 & 3.58 \\
4 & 1.59 & 3.87 & 3.60 \\
5 & 1.57 & 3.90 & 3.64 \\
6 & 1.58 & 3.90 & 3.63 \\
Average & 1.56 & 3.86 & 3.60 \\
S.D. & 0.02 & 0.03 & 0.03 \\
RSD (\%) & 1.28 & 0.78 & 0.83 \\
\hline
\end{tabular}

試験法は誘導体化操作を含めて測定值に対する妥当 性の問題はなく，外部滑沢打錠法により製された錠 剂を始めとする実製剤の $\mathrm{Mg}-\mathrm{St}$ 定量に使用可能で あることを検証した。

3. 市販製剤中の Mg-St の定量 既に市販さ れ，一般に流通している 4 製剤につき，各ロット繰 り返し 3 回の $\mathrm{Mg}-\mathrm{St}$ 定量を行った結果を Table 4 に示す。各製剤とも， $\mathrm{Mg}-\mathrm{St}$ の処方量（labeled amount）に近似した測定值が得られ，また，繰り 返し 3 回測定での RSD（\%）は 0.67-2.13\%と良 好な結果が得られた。

結論

HPLC による Mg-St の高感度分離分析法の確立 を目的に, $\mathrm{Mg}-\mathrm{St}$ からのステアリン酸及びパルミ チン酸の前処理方法及び HPLC 条件を検討した. 
Table 4. Assay of Magnesium Stearate in Commercially Available Pharmaceutical Preparations

\begin{tabular}{ccccc}
\hline \hline \multirow{2}{*}{ Repetition } & \multicolumn{4}{c}{ Quantity of magnesium stearate in commercially available pharmaceutical preparations (w/w\%) } \\
\cline { 2 - 4 } & Product A & Product P & Product N & Product C \\
\hline 1 & 0.86 & 0.99 & 1.18 & 1.86 \\
2 & 0.86 & 1.01 & 1.17 & 1.94 \\
3 & 0.87 & 1.00 & 1.14 & 1.89 \\
Average & 0.86 & 1.00 & 0.0208 & 0.0404 \\
S.D. & 0.0058 & 0.0100 & 1.79 & 2.13 \\
RSD (\%) & 0.67 & 1.00 & $(1.20)$ & $(1.95)$ \\
\hline
\end{tabular}

高感度化を目的とし，2-NPH によるUV 検出用プ レカラム誘導体化を行った，その結果，ステアリン 酸誘導体とパルミチン酸誘導体の良好な分離を保ち つつ，検出波長 $230 \mathrm{~nm}$ における注入試料濃度範 囲：0.00-0.04 mg/ml（設定した試験法に従い $\mathrm{Mg}$ -St として $0.1 \mathrm{mg}$ の試料を秤取した場合の $0.0-0.2$ \%に相当）で各々のピークは良好な直線性を示し た。また，検出限界は $2 \mu \mathrm{g}$ ，定量限界は $6 \mu \mathrm{g}$ であ つた。さらに 3 水準での回収率による併行精度は RSD（\%）が 2.9\%であり，他成分と $\mathrm{Mg}$ 量が重複 する製剤での $\mathrm{Mg}-\mathrm{St}$ 高感度分析法としての妥当性 が検証できた.

また，市販されている錠剤中の $\mathrm{Mg}-\mathrm{St}$ 分析を本 法により行ったところ，処方量として記載されてい る值に近似した良好な実測值を得ることができた。 よって，本法は製剂中の $\mathrm{Mg}-\mathrm{St} の ，$ 特に $\mathrm{Mg}$ が混 在する系において，高選択的微量分析法として実用 的利用価值の高い方法であると判断した.

\section{REFERENCES}

1) "14th Edition Japanese Pharmacopoeia (the explanation)," Hirokawa-syoten, 2001, pp.
D574-D578.

2) "U. S. Pharmacopeia $27 /$ National Formulary 22," 2004, pp. 2889-2890.

3) Oneda Y., Seizai Kikai Gijutsu KenkyuKaishi, 12, 311-319 (2003).

4) Taniguchi Y., Hibino T., Hasegawa M., Sunada H., "Hyojun Syohou Kenkyuukai Kouen Youshisyu," 2001, p. 55.

5) Nishimura K., Suzuki T., Katsura E., Itabashi Y., Bunseki Kagaku, 6, 533-539 (2004).

6) Baty J. D., Willis R. G., Biomed. Mass. Spectrom., 12, 565 (1985).

7) Nimura N., Kinoshita T., Anal. Lett., 13, 191 (1980).

8) Miwa H., Hiyama C., Yamamoto M., $J$. Chromatogr., 321, 165-174 (1985).

9) Miwa H., Hiyama C., Yamamoto M., J. Chromatogr., 416, 237 (1987).

10) Kouno S., Gouda R., Kobayashi M., Murakita H., Shimadzu Hyouron, 59 [1 - 2], 3-12 (2002).

11) Nguyet A. N., Tallieu L., Plaizier-Vercammen J., Massart D. L., Heyden Y. V., J. Pharm. Biomed. Anal., 32, 1-19 (2003). 